\title{
MLL/ARHGAP26 Fusion Protein
}

National Cancer Institute

\section{Source}

National Cancer Institute. MLL/ARHGAP26 Fusion Protein. NCI Thesaurus. Code C99338.

A fusion protein encoded by the MLL/ARHGAP26 fusion gene. This protein is comprised of the $\mathrm{N}$-terminal half of the histone-lysine $\mathrm{N}$-methyltransferase MLL protein, including the AT hook DNA binding domain and the DNA methyltransferase domain, fused with the C-terminal SH3 domain of the Rho GT Pase-activating protein 26. 